\title{
Pengaruh Fungsi Kepemimpinan Kepala Kantor Cabang Pembantu dan Iklim Organisasi terhadap Profesionalitas Pegawai pada Kantor Cabang Pembantu Bank BJB Syariah
}

\author{
Handri Rahmat Ilahi ${ }^{1}$, Wresni Pujiyati ${ }^{2}$, Ipong Dekawati ${ }^{3}$ \\ Pasca-Sarjana Manajemen Pendidikan, Universitas Wiralodra ${ }^{123}$ \\ Email Korespondesi: wresni.pujiyati@unwir.ac.id
}

\begin{abstract}
ABSTRAK: Fokus kajian peneliti ini diarahkan pada faktor-faktor yang mempengaruhi profesionalitas pegawai. Penelitian dilakukan di lima kantor cabang pembantu Bank BJB Syariah Wilayah Bogor. Didasari oleh fungsi kepemimpinan kepala kantor cabang pembantu dan iklim organisasi merupakan faktor yang diduga memiliki pengaruh terhadap profesionalitas pegawai. Oleh karena itu, penelitian mengkaji tiga variabel yaitu fungsi kepemimpinan kepala kantor cabang pembantu (X1), iklim organisasi (X2), dan profesionalitas pegawai (Y). Penelitian menggunakan pendekatan kuantitatif, dengan metode deskriptif dan verifikatif. Teknik pengumpulan data menggunakan angket. Adapun responden adalah pegawai Bank BJB Syariah kantor cabang pembantu wilayah Bogor. Teknik analisis data menggunakan analisis regresi. Penelitian ini menemukan jika fungsi kepemimpinan kepala kantor cabang pembantu berada pada kategori sangat baik. Iklim organisasi berada pada kategori sangat baik, dan profesionalitas pegawai kantor cabang pembantu Bank BJB Syariah wilayah Bogor berada pada kategori sangat baik. Berdasarkan hasil analisis regresi, diperoleh hasil bahwa fungsi kepemimpinan kepala kantor cabang pembantu dan iklim organisasi baik secara parsial maupun simultan memiliki pengaruh yang positif dan signifikan terhadap profesionalitas pegawai.
\end{abstract}

Kata Kunci: Kepemimpinan, Iklim Organisasi, Profesionalitas Pegawai.

ABSTRACT: This research focuses on studying factors that affect the professionalism of employees. The research was conducted in five sub-branch offices of Bank BJB Syariah, Bogor Region. Based on the leadership function of the head of the sub-branch office and the organizational climate are factors that are thought to have an influence on employee professionalism. Therefore, the study examines three variables, namely the leadership function of the head of a sub-branch office (X1), organizational climate (X2), and employee professionalism $(\mathrm{Y})$. This research uses a quantitative approach, with descriptive and verification methods. The data collection technique used a questionnaire. The respondents are employees of Bank BJB Syariah, Bogor sub-branch office. The data analysis technique used regression analysis. This study found that the leadership function of the head of a subbranch office is in the very good category. The organizational climate is in the very good category, and the professionalism of the employees of the Bank BJB Syariah sub-branch offices in the Bogor area is in the very good category. Based on the results of regression analysis, the results show that the leadership function of the head of the sub-branch office and the organizational climate either partially or simultaneously has a positive and significant effect on employee professionalism.

Keywords: Employee Professionalism, Leadership, Organizational Climate.

\section{PENDAHULUAN}

Kekhawatiran akan praktek profesional di masa depan muncul (Ashton, 2011). Profesional identik dengan keterampilan teknis yang didukung oleh pengetahuan dan sikap serta dilandasi oleh norma-norma (Pamungkas \& Jabar, 2014). Syarat yang harus

dimiliki oleh seseorang profesional, yaitu
memiliki kompetensi atau menguasai
pekerjaan, Seseorang layak disebut
profesional apabila ia tahu betul apa yang
harus dikerjakan dan bagaimana
melakukannya. Pengetahuan terhadap
pekerjaannya ini harus dapat dibuktikan


dengan hasil yang dicapai. Untuk menilai apakah seseorang menguasai pekerjaannya, dapat dilihat dari tiga hal yang pokok, yaitu: bagaimana ia bekerja, bagaimana ia mengatasi persoalan, dan bagaimana ia akan mencapai hasil kerjannya (Widjio, 2001). Profesionalitas pegawai kantor cabang pembantu Bank BJB Syariah khususnya wilayah Kantor Cabang Bogor berkaitan dengan profesionalitas pegawai berdasarkan hasil pengamatan penulis dirasa belum optimal. Dilihat dari kriteria atau syaratsyarat seorang yang profesional sebagaimana yang dipaparkan sebelumnya, khususnya pada kompetensi dan loyalitas pegawai, terlihat bahwa tingkat turnover atau resign pegawai Bank BJB Syariah di wilayah Bogor bisa dikatakan cukup tinggi. Selain itu masih cukup banyak catatan auditor internal dalam Data Temuan Audit (DTA) atas pelanggaran Standar Operasional Prosedur (SOP) dan ketentuan internal mengindikasikan masih banyaknya pegawai kantor cabang pembantu Bank BJB Syariah khususnnya wilayah Bogor yang masih belum menguasai SOP. Indikator lain yang mengindikasikan kurangnya profesionalitas pegawai Bank BJB Syariah terlihat dari kurangnya motivasi para pegawai dalam bekerja, hal ini terlihat dari tingginya tingkat keterlambatan masuk kerja para pegawai dan kurangnya kegiatan-kegiatan non formal yang dapat mendukung terbentuknya kondisi organisasi yang kondusif.

Rumusan masalah penelitian ini adalah: 1) Adakah pengaruh fungsi kepemimpinan Kepala kantor cabang pembantu dan iklim organisasi terhadap profesionalitas pegawai Bank BJB Syariah di wilayah Bogor?; 2) Seberapa besar pengaruh fungsi kepemimpinan Kepala kantor cabang pembantu terhadap terhadap profesionalitas pegawai Bank BJB Syariah di wilayah Bogor?; 3) Seberapa besar pengaruh iklim organisasi terhadap profesionalitas pegawai Bank BJB Syariah di wilayah Bogor?; 4) Seberapa besar pengaruh fungsi kepemimpinan Kepala kantor cabang pembantu dan iklim organisasi terhadap profesionalitas pegawai Bank BJB Syariah di wilayah Bogor?

\section{Profesionalitas Pegawai}

Seseorang dikatakan profesional apabila pekerjaannya memiliki ciri standar teknis atau etika suatu profesi (Poerwopoespito \& Oetomo, 2000). Profesionalitas mencerminkan sikap seseorang terhadap pekerjaannya, yaitu perilaku, cara, dan kualitas suatu profesi. Profesionalitas dapat diartikan sebagai suatu kemampuan dan keterampilan seseorang dalam melakukan pekerjaan menurut bidang dan tingkatan masing-masing. Profesionalitas menyangkut kecocokan antara kemampuan yang dimiliki oleh birokrasi dengan kebutuhan tugas, terpenuhi kecocokan antara kemampuan dengan kebutuhan tugas merupakan syarat terbentuknya pegawai yang profesional. Artinya keahlian dan kemampuan pegawai merefleksikan arah dan tujuan yang ingin di capai oleh sebuah organisasi (Kurniawan, 2005). Profesionalitas adalah pilar yang akan menempatkan birokrasi sebagai mesin efektif bagi pemerintah dan sebagai parameter kecakapan pegawai dalam bekerja secara baik (Sedarmayanti, 2010). Ukuran profesionalisme adalah kompetensi, efektivitas, dan efisiensi serta bertanggung jawab (Siagian, 2010).

Profesionalitas adalah pilar yang akan menempatkan birokrasi sebagai mesin efektif bagi pemerintah dan sebagai parameter kecakapan pegawai dalam bekerja secara baik (Sedarmayanti, 2010) delapan dimensi atau syarat yang harus dimiliki oleh seseorang profesional, ((Widjio, 2001) yaitu:

1. Memiliki kompetensi atau menguasai pekerjaan, Seseorang layak disebut profesional apabila ia tahu betul apa yang harus dikerjakan dan bagaimana melakukannya. Pengetahuan terhadap pekerjaannya ini harus dapat dibuktikan dengan hasil yang dicapai. Untuk menilai apakah seseorang menguasai pekerjaannya, dapat dilihat dari tiga hal yang pokok, yaitu: bagaimana ia bekerja, bagaimana ia mengatasi persoalan, dan bagaimana ia akan mencapai hasil kerjannya. Dengan begitu, maka seorang 
profesional akan menjadikan dirinya sebagai problem solver (pemecah persoalan), bukan jadi trouble maker (pencipta masalah) bagi pekerjaannya.

2. Mampu bekerja keras, Seorang profesional akan secara sadar sanggup untuk bekerja keras dalam menyelesaikan tugas dan tanggung jawabnya.

3. Loyalitas, Loyalitas bagi seorang profesional memberikan petunjuk bahwa dalam melakukan pekerjaannya, ia bersikap total. Seorang profesional memiliki suatu prinsip hidup, bahwa apa yang dikerjakannya bukan suatu beban, tetapi merupakan panggilan hidup untuk berkarya dan memberikan manfaat bagi orang lain. Maka, tak berlebihan bila mereka bekerja sungguh-sungguh. Loyalitas akan memberikan daya dan kekuatan untuk berkembang dan selalu mencari hal-hal yang terbaik bagi pekerjaannya, tanpa menunggu perintah. Dengan adanya loyalitas, ia akan selalu berpikir proaktif, yaitu selalu melakukan usaha-usaha antisipasi agar hal-hal yang fatal tidak terjadi.

4. Integritas, Nilai-nilai kejujuran, kebenaran, dan keadilan harus benar-benar jadi prinsip dasar bagi seorang yang profesional. Dengan integritas ini seorang profesional akan mempunyai kesadaran diri bahwa dalam melakukan suatu pekerjaan, hati nurani dan suara hati harus tetap menjadi dasar dan arah untuk mewujudkan tujuannya. Maka, tidaklah berlebihan apabila dikatakan bahwa seorang profesional tak cukup hanya cerdas dan pintar secara intelektual, tapi juga sisi mental dan emosional.

5. Visi, seorang profesional harus mempunyai visi atau pandangan yang jelas akan masa depan. Visi ini bisa dianggap sebagai peta jalan menuju masa depan yang dengannya ia akan memilki dasar dan landasan yang kuat untuk mengarahkan pikiran, sikap, prilaku dan tindakannya terfokus pada tujuan yang akan dicapai.

6. Kebanggaan, seorang profesional harus mempunyai kebanggaan terhadap profesinya. Apapun profesi atau jabatannya, seorang profesional harus mempunyai penghargaan yang setinggitingginya terhadap profesi tersebut. Karena dengan rasa bangga tersebut, ia akan mempunyai rasa cinta terhadap profesinya. ia akan mempunyai komitmen yang tinggi terhadap apa yang dilakukakannya, sehingga mengerakan dirinya untuk mencari hal-hal yang lebih baik dan senantiasa memberikan kontribusi yang besar terhadap apa yang ia lakukan.

7. Komitmen, seorang profesional harus memiliki komitmen tinggi untuk tetap menjaga profesionalitasnya. Artinya, ia tidak akan begitu mudah tergoda oleh bujuk rayu yang akan menghancurkan nilai-nilai profesi. la tidak akan mengorbankan idealismenya sebagai seorang yang profesional hanya disebabkan oleh hasutan harta, pangkat dan jabatan.

8. Motivasi, dalam situasi dan kondisi apapun, seorang profesional tetap harus bersemangat dalam melakukan apa yang menjadi tanggung jawabnya. Artinya, seburuk apapun kondisi dan situasinya, ia harus mampu memotivasi dirinya sendiri untuk tetap dapat mewujudkan hasil yang maksimal tanpa kenal menyerah. la akan menjadi motivator bagi dirinya sendiri, sehingga dapat membangkitkan kelesuankelesuan yang disebabkan oleh situasi dan kondisi yang dihadapi. Disamping itu ia juga harus mampu menyemangati lingkungannya. la mengerti, kapan dan di saat-saat seperti apa ia harus 
memberikan motivasi untuk dirinya sendiri dan lingkungannya.

\section{Kepemimpinan Kepala Cabang Pembantu}

Kepemimpinan adalah upaya

mempengaruhi orang lain dalam mencapai suatu tujuan sesuai dengan situasi organisasi (Blanchard, 2001). Kepemimpinan, selain terkait dengan proses memimpin, merupakan interaksi sosial antara pemimpin dengan pengikut, serta kepemimpinan adalah suatu seni. Kepemimpinan adalah suatu proses, memerlukan pengaruh, terjadi dalam pengaturan kelompok, dan melibatkan tujuan serta visi bersama (Pujiyati, 2019). Fungsi Kepemimpinan secara operasional dapat dibedakan dalam lima fungsi pokok kepemimpinan, yaitu: 1) Fungsi instruksi; 2) Fungsi konsultasi: 3) Fungsi partisipasi; 4) Fungsi delegasi; dan 5) Fungsi pengendalian (Rivai, 2007).

Berdasarkan struktur organisasi bank bjb syariah, Kepala Kantor Cabang Pembantu adalah seorang individu yang diberikan amanah oleh perusahaan untuk menjalankan bisnis dan opersional bank, mewakili direksi untuk menjalankan hubungan bisnis dengan pihak lain sesuai dengan limit kewenangan yang diberikan. Kepala Kantor Cabang Pembantu merupakan pemimpin tertinggi pada struktur organisasi Kantor Cabang Pembantu. Kantor Cabang Pembantu berada dibawah koordinasi Kantot Cabang. Kepala Cabang Pembantu dalam hal ini berada di bawah garis komando Pemimpin Cabang. Pemimpin Kantor Cabang berperan sebagai atasan langsung dari Kepala Kantor Cabang Pembantu. Kepemimpinan Kepala Kantor Cabang Pembantu adalah kemampuan seorang Pemimpin kantor Cabang pembantu untuk menggerakkan segala sumber yang ada pada kantor cabang pembantu sehingga dapat didayagunakan secara maksimal untuk mencapai tujuan yang telah ditetapkan.

\section{Iklim Organisasi}

Iklim organisasi merupakan lingkungan organisasi yang relatif statis yang berakar pada sistem nilai organisasi (Wirawan, 2007). Iklim organisasi dibagi menjadi 2 macam yaitu iklim organisasi terbuka dan tertutup (Pamungkas \& Jabar, 2014).

a. klim organisasi terbuka. Ditandai dengan adanya kerjasama yang baik dan respek terhadap lingkungan secara nyata antara warga kantor dengan kepala kantor cabang pembantu.

b. Iklim organisasi tertutup. Menunjukan hal yang sebaliknya dengan iklim organisasi yang terbuka.

Pengukuran iklim organisasi kantor dikelompokan ke dalam empat kategori, yaitu safety, teaching and learning, interpersonal relationships, institutional environtment.

Kategori pertama safety terdiri: (1) aturan dan norma, meliputi adanya aturan yang dikomunikasikan dengan jelas dan dilaksanakan secara konsisten; (2) fisik, meliputi perasaan pegawai yang merasa aman dari kerugian fisik di kantor; dan (3) sosial dan emosional, meliputi perasaan pegawai yang merasa aman dari cemoohan, sindiran, dan pengecualian.

Kategori kedua teaching and learning terdiri: (1) dukungan belajar, meliputi adanya dukungan terhadap praktek-praktek pengajaran, seperti tanggapan yang positif dan konstruktif, dorongan untuk mengambil risiko, tantangan akademik, perhatian individual, dan kesempatan untuk menunjukkan pengetahuan dan keterampilan dalam berbagai cara; (2) social and civic learning, menunjukkan adanya dukungan untuk pengembangan pengetahuan dan keterampilan sosial dan kemasyarakatan, termasuk mendengarkan secara efektif, pemecahan masalah, refleksi dan tanggung jawab, serta pembuatan keputusan yang etis.

Kategori ketiga interpersonal relationships berupa menunjukan adanya jaringan hubungan yang baik, menunjukan adanya kerjasama yang saling mempercayai, menunjukkan adanya sikap saling menghargai terhadap perbedaan individu pada semua tingkatan, yaitu antara pegawai dengan pegawai, dan pegawai dengan kepala kantor. Kategori keempat institutional environment, terdiri dari: (1) school 
connectedness/engagement, meliputi ikatan positif dengan kantor, rasa memiliki, dan norma-norma umum untuk berpartisipasi dalam kehidupan kantor pegawai dan keluarga; dan (2) physical surroundings, meliputi kebersihan, ketertiban, dan daya tarik fasilitas dan sumber daya dan material yang memadai (Pratiwi, 2012).
Penelitian ini menggunakan pendekatan kuantitatif dengan metode deskriptif dan verifikatif. Populasi dalam penelitian ini adalah Pegawai Bank BJB Syariah wilayah Bogor yang berjumlah 111 orang dengan sampel sebanyak 87 orang. Rincian populasi dan sampel di susun pada tabel 1 dan tabel 2 . Teknik pengolahan data melalui analisis regresi.

\section{METODE PENELITIAN}

Tabel 1 Populasi Penelitian

\begin{tabular}{|c|l|c|}
\hline No & \multicolumn{1}{|c|}{ Nama Kantor } & Jumlah Pegawai \\
\hline 1 & Kantor Cabang Pembantu Cibubur & 22 Orang \\
\hline 2 & Kantor Cabang Pembantu Jembatan Merah & 22 Orang \\
\hline 3 & Kantor Cabang Pembantu Depok & 23 Orang \\
\hline 4 & Kantor Cabang Pembantu Sawangan & 22 Orang \\
\hline 5 & Kantor Cabang Pembantu Cibinong & 22 Orang \\
\hline JUMLAH & $\mathbf{1 1 1}$ \\
\hline
\end{tabular}

Sumber: Divisi Sumber Daya Insani bank bjb syariah

Tabel 2

Sampel Penelitian

\begin{tabular}{|c|l|c|c|c|}
\hline No & \multicolumn{1}{|c|}{ Nama Kantor } & Jumlah Pegawai & Perhitungan & Sampel \\
\hline 1 & KCP Cibubur & 22 Orang & $(22 / 111) 87$ & 17 \\
\hline 2 & KCP Jembatan Merah & 22 Orang & $(22 / 111) 87$ & 17 \\
\hline 3 & KCP Depok & 23 Orang & $(23 / 111) 87$ & 19 \\
\hline 4 & KCP Sawangan & 22 Orang & $(22 / 111) 87$ & 17 \\
\hline 5 & KCP Cibinong & 22 Orang & $(22 / 111) 87$ & 17 \\
\hline JUMLAH & $\mathbf{1 1 1}$ Orang & & $\mathbf{8 7}$ \\
\hline
\end{tabular}

\section{Variabel Fungsi Kepemimpinan Kepala} Kantor Cabang Pembantu

Fungsi Kepemimpinan Kepala Kantor Cabang Pembantu adalah skor yang diperoleh dari jawaban responden dengan menggunakan kuesioner tentang Fungsi Kepemimpinan Kepala Kantor Cabang Pembantu, yang diukur melalui dimensi 1) instruksi dengan indikator a) arahan kerja b) perintah dengan jelas, 2) konsultasi dengan indikator kesempatan berpendapat dan bermusyawarah b) menerima kritik dan saran c) bimbingan yang tepat d) keluhan didengar dan menjadi perhatian , 3) partisipasi dengan indikator a) keterlibatan dalam pemecahan masalah b) keterlibatan dalam membantu pekerjaan c) perhatian kepada bawahan, 4) delegasi dengan indikator a) ketepatan dalam pemberian tugas b) intensitas pemecahan masalah pekerjaan pegawai c) komunikasi secara efektif, 5) pengendalian dengan indikator a) pengawasan yang intensif $b$ ) evaluasi tugas dan program kerja.

\section{Variabel Iklim Organisasi}

Iklim organisasi adalah skor yang diperoleh dari jawaban responden dengan menggunakan perangkat kuesioner tentang iklim organisasi, yang diukur malalui dimensi 1) safety dengan indikator a) aspek fisik: tata tertib da standar keamanan fasilitas kantor b) sosial dan emosional: sikap terhadap perbedaa sikap dan respon, 2) teaching and learning dengan indikator a) dukungan belajar dan kualitas pembelajaran b) dukungan pengembangan pengetahuan dan ketrampilan sosial melalui pelatihan c) komunikasi, 3) interpersonal relationships a) jaringan hubungan yang baik b) kerjasama yang saling mempercayai c) menhargai perbedaan inividu, 4) institutional environtment dengan indikator 
a) ikatan positif dengan perusahaan b) partisipasi dalam kehidupan kantor c) kebersihan lingkungan kantor d) penggunaan fasilitas kantor.

\section{Variabel Profesionalitas Pegawai}

Profesionalitas pegawai adalah skor yang diperoleh dari jawaban responden dengan menggunakan perangkat kuesioner tentang profesionalitas pegawai yang diukur melalui dimensi:

1. Kompetensi dengan indikator pengetahuan terhadap standar SOP, dan kemampuan melaksanakan pekerjaan;

2. Efektivitas dengan indikator kuantitas pekerjaan yang diselesaikan, kualitas pekerjaan, dan waktu yang dibutuhkan untuk menyelesaikan pekerjaan;

3. Efisiensi dengan indikator biaya yang dibutuhkan dalam menjalankan pekerjaan, waktu pelayanan;

4. Tanggung jawab dengan indikator menyelesaikan tugas dengan baik, ketepatan waktu, serta berani dan ikhlas memikul resiko.

\section{HASIL PENELITIAN DAN PEMBAHASAN}

\section{Hasil Penelitian}

Data Fungsi Kepemimpinan Kepala Kantor Cabang Pembantu

Angket mengenai fungsi kepemimpinan kepala Kantor Cabang Pembantu di sebarkan ke 87 responden dengan 18 item pertanyaan yang telah teruji validitas dan reliabilitasnya. Jumlah skor fungsi kepemimpinan Kepala Kantor Cabang Pembantu adalah 6.760 dengan rata-rata 77,70 standar deviasi sebesar 5,362, serta varians 28,747 . Sedangkan skor tertinggi dalam angket variabel ini yaitu 90 dan skor terendahnya 64 . Skor ideal variabel fungsi kepemimpinan kepala kantor cabang pembantu adalah 90. Dari hasil angka persentase skor tanggapan responden menunjukan bahwa fungsi kepemimpinan kepala kantor cabang pembantu Bank BJB Syariah di wilayah Bogor dapat dinyatakan sangat baik.

Angka persentase dimensi-dimensi tersebut dapat dilihat pada grafik Gambar 1.

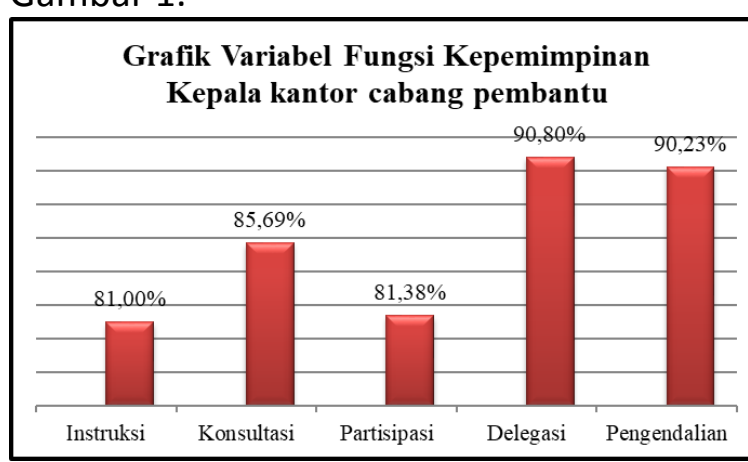

Gambar 1 Grafik Persentase Variabel Fungsi Kepemimpinan Kepala Kantor Cabang Pembantu

Dari Gambar 1 di atas dapat dilihat bahwa dimensi fungsi kepemimpinan kepala kantor cabang pembantu yang angka persentasenya paling tinggi yaitu delegasi sebesar $90,80 \%$ dan yang paling rendah adalah instruksi sebesar $81,00 \%$.

\section{Data Iklim Organisasi}

Angket mengenai iklim organisasi di sebarkan ke 87 responden dengan 20 item pertanyaan yang telah teruji validitas dan reliabilitasnya. Jumlah skor iklim organisasi adalah 7.287 dengan rata-rata 83,76 standar deviasi sebesar 6,247 , serta varians 39,022 . Sedangkan skor tertinggi dalam angket variabel ini yaitu 99 dan skor terendahnya 67. Skor ideal variabel iklim organisasi adalah 100. Dari hasil angka persentase skor tanggapan responden menunjukan bahwa iklim organisasi pada kantor cabang pembantu Bank BJB Syariah di 
wilayah Bogor sudah dinyatakan sangat baik.

Angka presentase dimensidimensi tersebut dapat dilihat pada grafik Gambar 2.

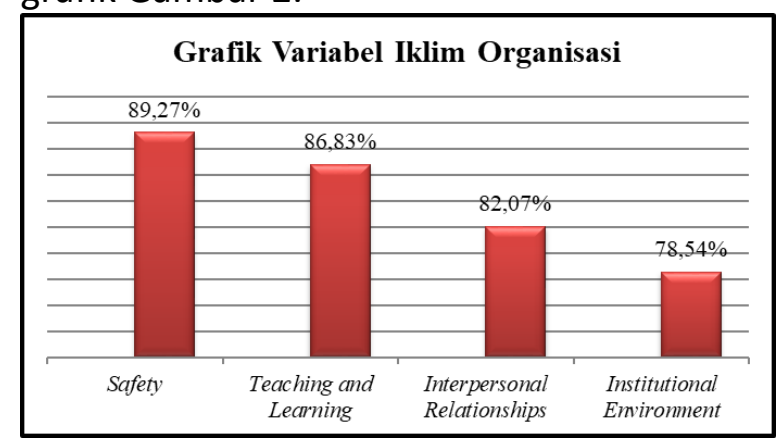

Gambar 2 Grafik Persentase Variabel Iklim Organisasi

Dari Gambar 2 diatas dapat dilihat bahwa angka prosentasenya yang paling tinggi yaitu safety sebesar $89,27 \%$ dan yang paling rendah adalah institutional environment yaitu sebesar $78,54 \%$. Sehingga iklim organisasi yang ditunjukan oleh pegawai kantor cabang pembantu Bank BJB Syariah di wilayah Bogor adalah sangat merasakan keamanan dan kenyamanan dalam bekerja.

\section{Data Profesionalitas Pegawai}

Angket mengenai Profesionalitas pegawai di sebarkan ke 87 responden dengan 18 item pertanyaan yang telah teruji validitas dan reabilitasnya. Jumlah skor Profesionalitas pegawai adalah 6.977 dengan rata-rata 80,20 standar deviasi sebesar 5,443, serta varians 29,624. Sedangkan skor tertinggi dalam angket variabel ini yaitu 89 dan skor terendahnya 65. Skor ideal variabel Profesionalitas pegawai adalah 90. Dari hasil angka persentase skor tanggapan responden menunjukan bahwa Profesionalitas pegawai pada kantor cabang pembantu Bank BJB Syariah wilayah Bogor sudah dapat dikatakan sangat baik.
Angka presentase dimensidimensi tersebut dapat dilihat pada grafik Gambar 3.

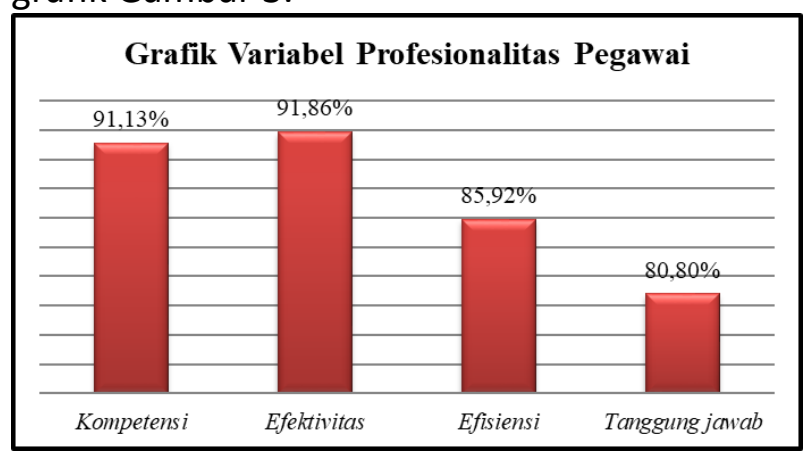

Gambar 3 Grafik Persentase Variabel Profesionalitas Pegawai

Dari Gambar 3 dapat dilihat bahwa profesionalitas pegawai yang angka presentase dimensinya yang paling tinggi yaitu efektivitas sebesar 91,86\% dan yang paling rendah adalah tanggung jawab yaitu sebesar $80,80 \%$. Sehingga Profesionalitas pegawai kantor cabang pembantu Bank BJB Syariah sangat efektif dalam menjalankan pekerjaannya.

\section{Pembahasan}

\section{Pengaruh Variabel Fungsi Kepemimpinan Kepala Kantor Cabang Pembantu (X1) terhadap Profesionalitas Pegawai (Y)}

Permasalahan yang dianalisis dari penelitian ini adalah "Seberapa besar pengaruh fungsi kepemimpinan kepala kantor cabang pembantu Bank BJB Syariah terhadap terhadap profesionalitas pegawai kantor cabang pembantu Bank BJB Syariah wilayah Bogor?"

Setelah dilakukan pengumpulan dan pengolahan data, didapatkan hasil bahwa penelitian ini berdistribusi normal, homogen, dan linier, maka peneliti melanjutkan pengujian hipotesis dengan menggunakan statistik parametrik. Pengujian hipotesis yang dilakukan bertujuan untuk membuat suatu kesimpulan bahwa variabel fungsi 
kepemimpinan kepala kantor cabang pembantu memiliki pengaruh positif terhadap variabel profesionalitas pegawai kantor cabang pembantu Bank BJB Syariah wilayah Bogor.

Berdasarkan pada perhitungan di atas dapat ditarik kesimpulannya bahwa "Terdapat pengaruh positif fungsi kepemimpinan kepala kantor cabang pembantu terhadap profesionalitas pegawai". Persamaan regresi linear sederhana untuk hipotesis variabel fungsi kepemimpinan kepala kantor cabang pembantu terhadap profesionalitas pegawai menunjukkan hubungan antara variabel berjalan satu arah dimana semakin tinggi fungsi kepemimpinan kepala kantor cabang pembantu, maka semakin tinggi profesionalitas pegawai, begitupun sebaliknya.

Hal ini sejalan dengan Andersen, dkk. 2018, pada penelitiannya tentang Achieving high quality through transformational leadership: $A$ qualitative multilevel analysis of transformational leadership and perceived professional quality. Bahwa Kepemimpinan, dalam hal ini kepemimpinan transformasional secara positf terkait dengan kualitas para profesional.

Penelitian terdahulu yang lainnya adalah tentang profesionalitas pegawai berjudul Pengaruh Profesionalisme, Komitmen Organisasi dan Kepuasan Kerja Terhadap Kinerja Karyawan Pada PT Bank Rakyat Indonesia (Persero) Cabang Manado, oleh Clara, dkk (2017), hasil dalam penelitian ini adalah profesionalisme memiliki hubungan signifikan terhadap kepuasan kerja dan memiliki pengaruh signifikan terhadap kinerja karyawan.
Pengaruh Variabel Iklim Organisasi (X2) terhadap Profesionalitas Pegawai (Y)

Permasalahan yang dianalisis dari penelitian ini adalah "Seberapa besar pengaruh iklim organisasi terhadap profesionalitas pegawai kantor cabang pembantu Bank BJB Syariah wilayah Bogor?"

Setelah dilakukan pengumpulan dan pengolahan data, didapatkan hasil bahwa penelitian ini berdistribusi normal, homogen, dan linier, maka peneliti melanjutkan pengujian hipotesis dengan menggunakan statistik parametrik. Pengujian hipotesis yang dilakukan bertujuan untuk membuat suatu kesimpulan bahwa variabel iklim organisasi memiliki pengaruh positif terhadap variabel profesionalitas pegawai kantor cabang pembantu Bank BJB Syariah wilayah Bogor.

Berdasarkan pada perhitungan di atas dapat ditarik kesimpulannya bahwa "Terdapat pengaruh positif iklim organisasi terhadap profesionalitas pegawai". Persamaan regresi linier sederhana untuk hipotesis variabel komitmen organisasi terhadap profesionalitas pegawai menunjukkan hubungan antara variabel bebas dengan variabel terikat berjalan satu arah, yang artinya setiap peningkatan atau penurunan di satu variabel, akan diikuti oleh peningkatan atau penurunan di satu variabel lainnya, sehingga apabila semakin tinggi iklim organisasi, maka semakin tinggi pula profesionalitas pegawai, begitupun sebaliknya.

Hal ini sejalan dengan Welsch \& LaVan, 1981 di penelitiannya tentang Inter-relationships between organizational commitment and job characteristics, job satisfaction, professional behavior, and organizational climate. Bahwa peran konflik, iklim partisipatif, kekuasaan, kerja tim, kepuasan kerja, promosi, usia, masa 
jabatan profesionalisme kerja berhubungan positif dengan komitmen organisasi.

Pengaruh Variabel $r$
Kepemimpinan Kungsi
Cabang Pembantu (X1) dan Iklim
Organisasi (X2) secara simultan
terhadap Profesionalitas Pegawai (Y)

Permasalahan yang dianalisis dari penelitian ini adalah "Seberapa besar pengaruh fungsi kepemimpinan kepala kantor cabang pembantu dan iklim organisasi terhadap profesionalitas pegawai kantor cabang pembantu Bank BJB Syariah wilayah Bogor ?"

Setelah dilakukan pengumpulan dan pengolahan data, didapatkan hasil bahwa penelitian ini berdistribusi homogen, dan linier, setelah itu dilakukan pengujian hipotesis dengan menggunakan statistik parametrik. Pengujian hipotesis yang dilakukan bertujuan untuk membuat suatu kesimpulan bahwa variabel fungsi kepemimpinan kepala kantor cabang pembantu dan iklim organisasi memiliki pengaruh positif secara simultan terhadap variabel profesionalitas pegawai kantor cabang pembantu Bank BJB Syariah wilayah Bogor.

Setelah dilakukannya perhitungan hipotesis regresi ganda, disimpulkan "terdapat pengaruh positif fungsi kepemimpinan kepala kantor cabang pembantu dan iklim organisasi terhadap profesionalitas pegawai"

Persamaan regresi ganda untuk hipotesis pengaruh profesionalitas dan komitmen organisasi terhadap kinerja pegawai menunjukkan hubungan antara variabel bebas dengan variabel terikat berjalan satu arah, yang artinya setiap peningkatan atau penurunan di satu variabel, akan diikuti oleh peningkatan atau penurunan di satu variabel lainnya, sehingga apabila semakin tinggi fungsi kepemimpinan kepala kantor cabang pembantu dan iklim organisasi guru maka semakin tinggi pula profesionalitas pegawai, begitupun sebaliknya. Ini sejalan dengan penelitian Budiman, A. (2017) dengan judul Pengaruh Kepemimpinan Dan Iklim Organisasi Terhadap Quality Of Work Life Serta Implikasinya Terhadap Kepuasan Kerja (Studi Kasus Pada PT Mediatama Binakreasi). Bahwa, Iklim organisasi berpengaruh terhadap kepuasan kerja. Iklim organisasi yang baik akan memberikan rasa nyaman bagi karyawan untuk melakukan aktivitas kerja. MManakala Rasa nyaman muncul pada saat melaksanakan aktivitas kerja, diperoleh kinerja yang positif.

\section{SIMPULAN}

Hasil analisis yang dipersepsikan dari jawaban responden menunjukan bahwa fungsi kepemimpinan kepala kantor cabang pembantu (X1) secara umum memiliki kategori sangat baik. Adapun pengaruhnya terhadap profesionalitas pegawai $(\mathrm{Y})$ pada kantor cabang pembantu Bank BJB Syariah wilayah Bogor sebesar 34,41\%, sisanya dipengaruhi oleh variabel iklim organisasi dan variabel lain yang tidak diteliti dalam penelitian ini.

\section{UCAPAN TERIMA KASIH}

Ucapan terimakasih peneliti kepada semua pihak yang telah membantu dalam penelitian yang telah dilakukan diucapkan terima kasih. Baik yang berkontribusi langsung maupun tidak langsung.

\section{DAFTAR PUSTAKA}

Andersen, L. B., Bjørnholt, B., Bro, L. L., \& Holm-Petersen, C. (2018). Achieving high quality through transformational leadership: A qualitative multilevel analysis of transformational leadership and perceived professional quality. 
Public Personnel Management, 47(1), 51-72.

Ashton, D. (2011). Media work and the creative industries. Education+ Training.

Blanchard, H. D. (2001). Management Of Organizational Behavior: Utilizing Human Resource. New Jersey: Prentice Hall.

Budiman, A. (2017). Pengaruh Kepemimpinan Dan Iklim Organisasi Terhadap Quality Of Work Life Serta Implikasinya Terhadap Kepuasan Kerja (Studi Kasus Pada Pt Mediatama Binakreasi). Jurnal Citra Widya Edukasi, 9(1), 1-8.

Hamalik, O. (2000). Psikologi Belajar dan Mengajar. Bandung : Sinar Baru.

Kurniawan, A. (2005). Transformasi Pelayanan Publik. Yogyakarta: Pembaruan.

Pamungkas, W., \& Jabar, C. (2014). Pengaruh Profesionalitas, Kepuasan Kerja, Iklim Organisasi terhadap Kinerja Guru SMKN di Kabupaten Boyolali.

Akuntabilitas Manajemen Pendidikan, 27.

Poerwopoespito, O. s., \& Oetomo, T. (2000). Mengatasi Krisis Manusia di Perusahaan. Jakarta : Grasindo.

Pratiwi, H. (2012). Hubungan Profesionalisme Guru dan Iklim Sekolah. Jakarta: UI.

Pujiyati, W. (2019). Kepemimpinan dan Perilaku Organisasi. Yogyakarta: K-Media

Rivai, V. (2007). Bank and Financial Institution. Jakarta: PT. Raja Grafindo Persada.

Rivai, V. (2013). Manajemen Sumber Daya Manusia Untuk Perusahaan Dari Teori Ke Praktek. Bandung: Raja Grafindo Persada.

Sedarmayanti. (2010). Sumber Daya Manusia dan Produktivitas Kerja . Bandung: Mandar Maju.
Siagian, S. P. (2010). Manajemen Sumber Daya Manusia. Jakarta : Bumi Aksara.

Waterkamp, C. I., Tawas, H. N., \& Mintardjo, C. (2017). Pengaruh Profesionalisme, Komitmen Organisasi Dan Kepuasan Kerja Terhadap Kinerja Karyawan pada PT. Bank Rakyat Indonesia (PERSERO) Cabang Manado. Jurnal EMBA: Jurnal Riset Ekonomi, Manajemen, Bisnis dan Akuntansi, 5(3).

Welsch, H. P., \& LaVan, H. (1981). Interrelationships between organizational commitment and job characteristics, job satisfaction, professional behavior, and organizational climate. Human relations, 34(12), 1079-1089.

Wirawan. (2007). Budaya dan Iklim Organisasi. Jakarta: Salemba Empat. 